\title{
SOLIDIFYING SYSTEM OF DEMOCRACY IN THE CENTRAL AND EASTERN EUROPEAN NEW EU MEMBERS
}

\author{
GYÖRGY JENEI \\ Full professor, Corvinus University of Budapest \\ E-mail: gyorgy.jenei@uni-corvinus.hu
}

\begin{abstract}
The paper examines the requirements of an effective and legitimized democratic political system in the process of transition. The analysis and the conclusions are based on the Hungarian experience, which can carefully be applied to all Central and Eastern European (CEE) countries. Special focus is given to the relationship of legal certainty and the efficiency of the democratic system, to the tension between legalism and managerialism and to the characteristics of civil society organizations. In the conclusion special features of the transitional countries are pointed out.
\end{abstract}

Keywords: transition, democracy, legalism, managerialism, civil society

JEL codes: H11. H83

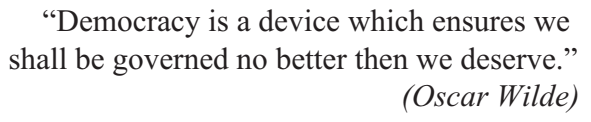

\section{INTRODUCTION}

It is evident that in the transition from command economy to market economy and from a totalitarian state to a pluralist state, creating multiparty democracy is not only a transition in itself but rather a long process of transformation. It requires essential reforms in the basic functions and institutions of the state (König 1992), and it requires the emergence or re-emergence of a civil society as well.

First of all we have to make a clear distinction between transition and transformation. The term "transition" refers to the beginning and the completion of a his- 
torical process. In that sense the Central and Eastern European (CEE) countries had a more or less common starting point, a party-state or a state-party system and in the coming 30-40 years they should manage to achieve the perfection of a market economy system and liberal democracy.

The term "transformation" covers the essential changes in the economy, society, and politics in the process. These transformation and transition processes have emerged on various historical backgrounds. There were differences in the starting point of the transition among the CEE countries and these differences have been deepened in the course of transition. This means that on one edge of the continuum one can find functioning market economies and liberal democracies while on the other edge of the continuum liberal democracy is not a real and existing system, but a mere instrument for the international legitimization of political systems which are closer to "enlightened absolutism" than a liberal democracy. The relationship among these various types can be characterized as a "diverging convergence".

It is the reason why the Hungarian experiments can be carefully applied to all CEE countries. Perhaps the reform and modernization processes of the new EU member and accession states from the region are more or less similar to the Hungarian pattern. For the other countries in the region this pattern is less relevant and in a few cases the development of liberal democracy would threaten the political stability in these countries.

\section{LIMITED LEGAL CERTAINTY OF THE DEMOCRATIC POLITICAL SYSTEM}

First, the basic task was the creation of a strong legal state. But the task was not so simple because in the European tradition there were three different Rechtsstaat models.

According to Walter Kickert (2008: 5-6) the basic difference between the Napoleonic and German models is the following:

The Napoleonic state model, in which the nation state is united and the state serves the general interest, the administration is centralized, hierarchical, uniform, accountable and controlled, and state officials are highly trained and qualified, and organized in professional 'corps', also formed the foundation of Mediterranean states like Italy, Spain and Portugal. The German Rechtsstaat tradition can be recognised in countries like Austria. The main difference between the legalistic Napoleonic and the German Rechtsstaat model is that the Prussian state formation was not based on a revolutionary abolishment of monarchy by the bourgeoisie, but on the hegemony of the Prussian elite, in particular the 'Iron Chancellor', Bismarck. The nineteenth-century German idea of Rechtsstaat meant that the sovereign was to be bound by laws and rules, which were to be equally and fairly applied to all state subjects, and that judges and administrators, were to be neutral. Contrary to the French principe 
de legalité, in which the law is the expression of the volonté générale, of the people (Ziller 2003), in Prussia and Habsburg Austria the emperors remained in absolute power. Parliamentary democracy was only established in Germany after the First World War.

The third model is the liberal constitutional Rechtsstaat established in the twentieth century in many West-European countries. According to Kickert:

[t]he establishment of the Rechtsstaat also marked the beginning of modern professional bureaucracy. State officials transformed from personal servants of the king into servants of the impersonal state. They became properly educated and trained professionals with the proper expertise, they fulfilled an official, formally described task, held a formal and protected life-long position, with regular salary and pension. The ideal-type of bureaucracy (Weber 1922) was born (Kickert 2008: 6).

What type of Rechtsstaat model was established in Hungary? The Napoleonic model can be excluded because the authoritarian system was not abolished in a revolutionary way. The Hungarian ambition and intention was to create a liberal constitutional Rechtsstaat based on the primacy of the law. Legal sources should be the basis of administrative actions implemented by a modern professional bureaucracy. In spite of the fact that Hungary followed the German Rechtsstaat model in the period of the Austro-Hungarian Monarchy there were no attempts for its renewal (Hajnal - Jenei 2008: 211-212). By now it turned out that serious deficiencies exist in the implementation of the Rechtsstaat model. Rechtsstaat requires the separation of the there basic power branches; the legislative, executive and judicial institutions. In Hungary the separation of judiciary from the two other power branches is not completed even by today.

The courts are influenced by the executive in different ways; for instance in their agenda setting and for slowing down judicial process. The extent and the forms of arbitrary actions is also an Achilles heel of the system. Politicians and bureaucrats are not demarcated in the commitment of bribery and corruption. Sometimes elected politicians are the initiators. Sometimes corruption is bottom up, when low level civil servants must give a certain share to their principal. But top-town corruption also occurs quite frequently when top level civil servants have to buy the silence of the others.

In Hungary one kilometer of highway costs double the amount of money than in Croatia. However it is well known that Hungarian highways are built on the great Hungarian plain and the Croatian highways are built in hilly regions. Corruption connected to public procurement and later on to public-private partnership (PPP) contracts proves that the autonomy of public administration is limited and it is dependent from the leaders of the political parties. The political parties not only restricted the autonomy of the public administration, but also politicized the activities of the bureaucracy. The result of the impact of the parties was a decrease in the professionalism of bureaucracy. 
This means that the legal-rational principle of the Weberian theory on bureaucracy was only partly accomplished. It turned out that no imitation of any Western model is possible, because of the impact of the Byzantine historical heritage. It resulted in that the legal-institutional framework was set up, but political behavior was not adequate to the framework and it caused serious deficiencies.

\section{PROBLEMS OF EFFICIENCY AND EFFECTIVENESS}

Democratic legitimacy has two components: legal certainty and efficiency. After the establishment of the legal-institutional framework, the increase in the performance of the economy and the public sector became an external requirement of Europeanization. The improvement of the infrastructure, the quality of public services, and the performance of public administration became key long-term factors of economic recovery and modernization.

Institutional capacity building became the core requirement, and public management reforms were the answers to the challenge. According to the typology of Pollitt and Bouckaert (2004), public management reforms in Hungary had begun on the modernizing trajectory in 1990. In the mid-1990s a shift has begun from modernization because of the weakness of the legal state. Then the accession to the European Union produced an external constraint to reinforce legalism and strengthen effectiveness at the same time. The cumulative deficiencies were confronted with new waves of external requirements and the result was a somehow chaotic situation.

Hungary has had an incomplete trajectory in an international perspective. From the three different contracts (contractual based relationship between the regulative and service delivery functions; contracting out for quality improvement; and the Citizen's Charter) only contracting out is applied in the Hungarian practice. The steering and rowing functions were not uncoupled. The day to day actions of the public agencies were not based on contracts between regulation and service provision. Only a performance appraisal system has been prepared without creating the institutional framework for correct performance measurement.

The consequence was that public agencies could not compete in the poorly regulated market of service delivery with private enterprises. No transparent mechanisms of accountability were built up for civil monitoring. Citizens were not empowered. No Citizen's Charter could and can be seen on the horizon.

State monopoly is being replaced with private monopoly. In one county of Hungary (where the ruling coalition has majority in the county assembly), three of the county's four hospitals have been contracted out to a private firm. (Leading officials from the government actually have investments in this "private firm".) This 
firm has made a bid for the fourth hospital with the support of the county assembly. The capital of the county however - where the hospital is located - resists. Let us suppose that the private firm will win and control the fourth hospital as well. Who will compete with whom? How can the public control them? Will the regulative power of the government be efficient?

\section{RELATIONSHIP BETWEEN LEGAL CERTAINTY AND EFFICIENCY}

It is well known that there are tensions between the principles of professional integrity and professional loyalty of the administrative principles of governance. And it is also known that there is a tension between legalism and managerialism manifested in the areas of customer orientation, quality improvement and application of management techniques. In spite of the fact that in the old EU countries the development of the rule of law and the introduction of public management reforms was a sequential, organic type of process, these tensions could be observed in there as well.

The basic difference in the new EU member countries of CEE is that the legal and organizational framework of the "Rechtsstaat" has only been established in the 1990s and shortly after they have also faced the challenge of introducing managerial methods and techniques in the pubic sector. In other words: basically the development of the rule of law and of the public management reforms has become a parallel process. The result is that the deficiencies and deviations from any Western patterns have been multiplied. Let us turn to these deficiencies.

First, in this region a special version of representative democracy has been implemented. In this version of democracy the political party leaders are supposed to be charismatic and democracy is meant for the citizens to participate only in the voting process. There are two problems with this type of democracy. First, strong social groups do not accept it. The public opinion polls show a frightening decline in the personal prestige of the politicians. Very limited confidence exists in the political institutions and in the public agencies as well. (A few local politicians are the exceptions, first of all the city mayors. This level of mistrust endangers the stability and the functioning of the democratic systems.) The second problem is - in the terms of the European standard of participative democracy - that the current tasks of the public sector's modernization require a post-parliamentary democracy.

In the new member countries participative democracy is only a demand of the trade unions and of several civil society organizations. In this special situation direct democracy is applied because of the lack of participative democracy, because 
it is the only - and costly - opportunity for pressure groups to express their criticism or resistance, and most importantly their contribution to governance.

In a comparative perspective we can raise the question: What model of democracy has emerged? Definitely it cannot be described with the terms of liberal democracy. The very essence of this model of democracy - between the consecutive elections - is widespread political participation, direct and active involvement of citizens as decision makers in public policy making. The CEE model does not meet these criteria, because the institutional mechanisms of participative involvement either have not been set up (mechanisms of civil dialogue) or if even they are established, they do not function in the day to day practice of policy making (mechanisms of social dialogue). These democracies are in a deadlock situation. The integrative political organizations, the pressure groups and the civil society organizations are not able to force the parties to move out from this deadlock of fragmentation. These democracies have unbalanced institutional backgrounds. The centrifugal forces (the parties) have essentially more strength and power then the centripetal, integrative forces (the trade-unions, pressure groups, civil society organizations). In some cases these centripetal, integrative forces only imitate their socio-political functions, because some of them were created by parties and therefore they are the extended arms of the various political parties.

The second deficiency is that public management reforms are not coupled with reforms in policy making. In 2005 the OECD published an analysis and evaluated the results and problems of the reforms. The main deficiencies of the CEE public sector - measuring them on the criteria of this overview - are the following:

- No progress has been made in transparency, accessibility and responsiveness.

- The openness of the government is on the traditional level.

- Performance management and budgeting have not been implemented in a series of public agencies.

- Public policy making exists only as a web of actions without a relevant strategy. We can mainly speak about strategic management on the local level.

- Progress has been made in the efficiency of some public agencies, but the implementation of effectiveness is only sporadic.

- There is a widespread abuse and mismanagement of the market type mechanisms.

- The core issue which has to be solved is the adaptation to the changing needs of the social groups and maintaining coherence of public policy and continuity of governance values at the same time.

The third reason of deficiencies is that the relationship between politicians and civil servants is not consolidated. It means that every change in the ruling coali- 
tion - which happens quite frequently in the CEE countries - has an impact on the composition of public administration on the top and the middle levels. It has been the main obstacle of building up a neutral and professional bureaucracy based on meritocracy. Party affiliation is much more important than professional expertise in the nomination of top and middle level bureaucrats.

The process has begun already in 1990 when top level technocrats were ousted from the government. In spite of the fact that their attitude was basically loyal to the new government, following the good old slogan originating from the time of the Austro-Hungarian Monarchy: "Maul halten und weiter dienen" (Shut up and keep on serving!)

This procedure was repeated every four years since 1990. Unfortunately there was an exchange in the governing position in almost every election. It was the result of a series of punishment votes and the opposition forces always emptied not only the key positions, but the mid-level positions as well. They had to pay their supporters. The ideology was: "democracy is a learning process". The problem was that they repeatedly learned, the public paid the costs, and a lot of the new leaders were weak, hopeless cases. It resulted in a decline in the professional expertise of civil servants. Sometimes civil servants do identify themselves as independent, but the question for them is "on which side are you independent?"

The situation is somewhat better on the local level. Either in cities or in villages continuity can be experienced. It is favorable for the development of professional expertise. But in the current situation the relationship between politics and administration is unstable and over-politicized.

Politicization of public administration is also characteristic for Western democracies (Goetz 2001), but in a comparative perspective the Hungarian practice is different from the prevailing modes of politicization in Western democracies (Meyer-Sahling 2008). The main differences are as follows:

- personnel turnover is essentially higher then the international standards after every elections;

- new appointees have been recruited from outside mainly based on their political affiliation rather then from the public agencies;

- governments appoint officials who are "returnees", as Meyer-Sahling argues "in the sense that they work in senior administrative ranks under governments of the same political couleur, leave when a government is formed by parties of the opposite political spectrum, but return to senior ranks with "their bloc of parties" after having bridged the out-of-office period in the private sector, academia or at a political party". 
A partisan politicization has emerged which is different from the other modes of politicization, namely non-politicization, and bounded politicization. This mode is the heritage of the authoritarian system where the politicization of public administration was strong and dominant. It was a one-party system, in which the career paths were merged among the leading positions of the party, public administration and economic enterprises. Unfortunately this party dominance survived the authoritarian system in a modified form. In the new multiparty systems the "ancient mode" of politicization has been preserved and it has been taken over by the newly established parties as well.

Are we really in a trap? Does a way out exists from this post-accession crisis? My answer is: yes, but there are certain preconditions to it. First the new EU member CEE countries must not try to avoid the Weberian phase of development. A functioning Rechtsstaat is a necessity in the course of modernization but you have to add to this development the application and implementation of public management reforms as well. You need a balanced position and public administration needs a stable political background and strong consensus of the political parties in supporting this process.

I argue that the possible solution is the Neo-Weberian State, in which governmental actions are based on the rule of law, in which private enterprises are involved in order to increase competition and quality in service delivery, and in which civil society organizations have a full range involvement in public policy making, from decision making to service provisions.

The Neo-Weberian State means that the light at the end of the tunnel is in sight and without this synthesis we are just running in a long tunnel further down, multiplying the deficiencies of modernization. There is no doubt: in a normative approach, the Neo-Weberian State would be the optimal solution. But taking into consideration the multiple deficiencies either of the legal state or of the public management reforms, and the controversies between the rhetoric and the actions of reform efforts another dangerous alternative appears on the horizon: the neo-patrimonial state.

It is sure that the neo-patrimonial alternative would be a dead-end street. Now we are just at the entrance of it. The only guarantee not to enter this street is the strengthening of civil sector and its organizations.

\section{THE ROLE OF CIVIL SOCIETY AND ITS ORGANIZATIONS}

CEE politicians typically divide society into a bi-polar spectrum: marketplace on the one side and government on the other. In this approach the civil society is dependent from these two centers. But we need an approach in which market econ- 
omy, government and civil society are integral parts of a there-legged stool. The first leg creates the market capital, he second one the public capital and the third one the social capital. The civil society has to develop and nurture this third, and independent force in public policy making. Thus the CEE goal cannot be other than to follow a Neo-Weberian synthesis and trying to avoid the mistake of a neo-patrimonial state.

The ongoing shift in the European Union from government to governance (van Kersbergen - van Waarden 2004) has changed the role of the civil society organizations and the civil society. Civil society was among the initiators of the shift to governance with its expectations and higher demands. And in the course of the shift, governance arrangements have emerged in the EU - at European, national and subnational levels - involving different actors, so-called stakeholders (not only state actors) such as business associations, lobby groups, public interest groups and service providers. The role of civil society includes the following two components:

- a constant external push requiring a shift toward governance, and

- an increasing role in the emergence of governance including an important role in network governance with growing influence on the bargaining and deliberation process of the regulatory policies and with an increasing role in the distributive policies mainly in service provision but in the decision making process as well. These reform efforts are partly consequences of the changing expectations of the civil society which are expressed through their organizations and directly in referenda but, on the other hand, they are challenges for them as well. Governance requires to strengthen legitimacy and to improve efficiency and effectiveness at the same time.

In the EU member countries in the past decades essential reform steps were taken in public governance and management. With the modernization and reform efforts, governments answered to the social, economic and technological challenges. In many cases these challenges were pressures and constraints. For example, the fiscal constraints or pressures on government expenditures have had decisive role in many EU member countries.

But it is quite obvious that the reform steps were triggered by a changing society with new and different expectations and by the demand of the third sector organizations for more involvement in service provision, for more empowerment in public policy making, and for a more efficient, more open and transparent, more customer oriented, more flexible, accessible and consultative government, more focused on performance. 
The expectations of civil society and the demands of its organizations are of essential importance in the shift form government to governance in the new EU member states as well; and in the strengthening of openness and transparency, in enhancing public sector performance, in modernizing accountability and control in the creation of new organizational settings, in the use of market-type mechanism in particular. So far, it is far from a completed process. We are in the middle of our way to create essentially new relationships between government and civil society and among market type, public, and third sector organizations.

It has been demonstrated during the last decades that the same reform steps resulted in quite diverse results in the different new EU member countries. The modernization process is context dependent, and the influence of the following factors is significant:

- the strength of the civil society,

- the capabilities of the civil society in articulating, expressing and implementing the interests of different social groups,

- the level of social capital, encompassing social trust,

- the level of vertical and horizontal value orientation in creating networks, the service provision power of third sector organizations,

- the demand of the civil society for making a shift from the "input legitimacy" of modern democracies to the "output legitimacy" of a "participatory democracy”.

In 2005 the role of the civil society and its organizations was evaluated in details in the context of basic European administrative principles by the OECD (2005). The main conclusions of the report which are relevant to our topic are as follows:

1. Openness and transparency - the two basic values of governance - are strongly emphasized requirements of the civil society. Increasing openness and transparency brings third sector and civil society organizations closer together.

1.1. When civil society receives relevant and understandable information on governance activities it means that civil society organizations' (CSO) activities also become open and transparent to the public. Openness and transparency are vital requirements for CSOs as well. Relevant and understandable information enhances the citizens' access to services and the opportunity to participate in decision making. The lack of relevant and understandable information however triggers falling levels of social trust. Citizens' trust is in CSOs is reduced when they are not informed about the specific activities of the CSOs. Therefore, CSOs are required to raise their 
own standards of openness and transparency - even accountability - in order to maintain their creditability and legitimacy toward civil society.

1.2. The creditability of CSOs depends on their public watchdog function as well. In a lot of public policy areas this function has been strengthened because CSOs are not amateur lobbyists anymore. They have evolved into highly professional organizations and they can monitor the government performance and they can provide understandable information on that for the public. There are traditional sources of independent monitoring of government performance (e.g. media, international organizations, rating agencies), CSOs have to become new, influential actors in monitoring activities, because, they can significantly increase the power pressures and vocal demands of the civil society for openness, transparency and accountability. Openness and transparency strengthen participatory democracy by providing more controlling opportunities for the civil society, by exposing abuse of power and corruption, by offering greater protection against mismanagement, and by providing greater opportunities for full range participation in decision making and in service provision.

1.3. Civil society has higher demands for an accessible and responsive decision making and public service provision. It is required not only toward the public agencies but toward the CSOs as well. The introduction of the so-called "Citizens' Charters" should legitimize the high quality public services and meets the expectations of citizens.

Nowadays CSOs are also required to improve accessibility. It is considered as a key element of service quality. CSOs have to simplify their administrative procedures and they have to provide assistance and advice in complying with regulations to the citizens in many cases through Interned-based portals and other electronic forms. Public agencies have been challenging CSOs with the expanding use of public consultation as well. This challenge requires from CSOs more responsibility through building broad consultation frameworks. The public consultation regularly organized by CSOs must have clear goals and rules. Formal institutional mechanisms and a system of case by case, informal consultations must be created and maintained as well.

2. Enhancing the performance level of CSOs is also an essential requirement. The main reason is that among new EU member countries more and more public agencies introduce performance-oriented budgeting and performance management. These trends are greatly appreciated by the civil society and citizens have an increasing demand toward CSOs for performance orientation in budgeting and management. 
Many CSOs already link expenditures to specific targets. The key issue is to what extent performance results determine budget allocations and whether the structure of expenditures is dependent from outcome targets as well. Furthermore, this provision provides access to information detailing to what extent rewards or sanctions are applied by CSOs when outcome targets are or are not met.

CSOs are challenged by public agencies and private enterprises in implementing performance management reforms. It is strongly recommended for CSOs to use performance results to set priorities of the projects and different activities, to allocate resources within the projects. A regular improvement of the decision making process is also needed based on monitoring type of project evaluation. More autonomy is to be given to the managers of CSOs in using resources for achieving results and improving performance.

In this context, the accountability to the citizens has to be improved. CSOs have to be accountable toward their members and toward their target groups with presenting relevant and understandable information aiming at the increase of public trust. The information has to cover not only the performance measures but also the quality and accuracy aspects of CSOs' activities.

Because of scandals and other harmful events public trust has declined toward CSOs as well. Therefore improvement of transparency and accountability is crucially important. It has to include reforms in the application of techniques of performance budgeting and management but also changing the behavior of CSO employees.

3. Another challenge for CSOs is the reorganization of their mechanisms and activities. It is a consequence of strategic partnership relationships between the CSOs, the public agencies, and the private sector organizations. CSOs have to compete with organizations from the other two sectors. In the process of reorganization new challenges can emerge. When a large number of organizations cooperate, civil society can develop a blurred picture of system functioning, management systems, and on reporting mechanisms.

The involvement of new stakeholders and the creation of more complex networking structures have risks for democratic control and accountability in the direction of civil society.

Reorganization of CSOs creates new relationships with their members, with the new stakeholders, and with other citizen groups. Reorganization has its benefits and risks and a regular, consensus-based balancing effort is needed among the main actors. 


\section{CONCLUSIONS}

To sum it up: in the new EU member countries - depending on differences in the economic, social and cultural context and on historical traditions - a diversity exists in the empowerment of civil societies and in the involvement of their organizations. However, some general requirements still should be drawn:

- The level of empowerment should be related to the ongoing shift from representative (output) democracy to the participatory (input) democracy.

- The bargaining and lobby power of civil society and its organizations has to be increased in the area of regulatory policy making.

- The service provision function of CSOs in different policy areas has grown significantly, but it should grow in the decision making processes of the distribution policies as well.

- Civic participation has to be strengthened through the emergence of a "civil dialogue" which has a different meaning from consultation to co-decision.

- CSOs have to be accepted and, accordingly, supported as having important economic and social roles in democratic societies.

- The multifunctional character of these organizations should be outlined by distinguishing between operational organizations with service delivery function and advocacy organizations aiming to have an impact on the policies of the government, on the behavior of public agencies and on the public opinion.

This means that civil society should contribute not only to the improvement of the input but also to the output legitimacy of democratic societies.

\section{REFERENCES}

Goetz, Klaus (2001): Making sense of post-communist central administration: Modernisation, Europeanisation or Latinisation? Journal of European Public Policy 8(6): 1032-1051.

Hajnal, György - Jenei, György (2008): The Study of Public Management in Hungary. In Kickert, Walter (ed.): The Study of Public Management in Europe and the US. London: Routledge, 208-233.

Kersbergen, K. v. - Waarden, F. v. (2004): Politics and the Transformation of Governance. Issues of Legitimacy, Accountability, and Governance in Political Science. European Journal of Political Research 43: 143-171.

Kickert, Walter (2008): The Study of Public Management in Europe and the US. London: Routledge.

König, Klaus (1992): The Transformation of a "Real-Socialist" Administrative System into a Conventional Western European System. International Review of Administrative Sciences 58: $147-176$. 
Meyer-Sahling, Jan-Hinrik (2008): The Changing Colours of the Post-communist state: The Politicisation of the Senior Civil Service in Hungary. European Journal of Political Research 47: $1-33$.

OECD (2005): Modernising Government: The Way Forward. Paris: OECD

Pollitt, Christopher - Bouckaert, Geert (2004): Public Management Reform, A Comparative Analysis. Oxford: University Press.

Weber, Max (1922/1972): Wirtschaft und Gesellschaft. Tübingen: Mohr

Ziller, Jacques (2003): The Continental System of Administrative Legality. In: Peters, Guy - Pierre, Jon (eds.): Handbook of Public Administration. London: Sage. 